\title{
MODEL UNTUK MENENTUKAN FAKTOR UTAMA YANG DIGUNAKAN UNTUK MENGUKUR BIAYA AUDIT
}

\author{
Sarlina Sari* \\ *Program Penelitian Akuntansi Universitas Bina Sarana Informatika \\ Email: sarlinasari.new@gmail.com
}

\begin{abstract}
This study aims to examine the factors that influence audit fees in manufacturing companies listed on the Indonesia Stock Exchange (BEI). Apart from that, it also aims to build a model for determining and measuring audit fees.

In this study, a multiple regression model was developed to test the factors that are expected to affect audit fees (such as: client size, profitability, client risk, client complexity, type of client industry, audit office status, audit report lag, audit rotation and audit committee independence). Data is collected from financial reports and annual reports available on the IDX website for the period 2014 to 2018.

The results of this study indicate that the main factors that have a significant effect on audit fees are: audit report lag, risk, client size, audit office status, and company complexity. Audit fees are negatively and significantly related to industry type and profitability. In addition, no relationship was detected between audit committee independence and audit rotation and audit fees.
\end{abstract}

Keywords: audit fees, client size, profitability, client risk, client complexity, type of client industry, audit office status, audit report lag, audit rotation and audit committee independence.

\section{PENDAHULUAN}

Pengendalian korupsi adalah topik yang menarik banyak perhatian akhir-akhir ini. Banyak diskusi telah dilakukan baik di sektor swasta maupun publik tentang metode "anti-korupsi" apa yang dapat diterapkan. Sejak kasus Enron dan Arthur Andersen, terdapat kebutuhan yang semakin meningkat terhadap peraturan baru untuk meningkatkan tata kelola perusahaan. Akibatnya, Sarbanes Oxley Act (SOX) dikeluarkan pada tahun 2002 untuk mengamankan investor dari kemungkinan kegiatan akuntansi yang curang oleh perusahaan dan untuk mengamanatkan reformasi yang ketat untuk meningkatkan pengungkapan keuangan dan mencegah penipuan akuntansi.

Profesi audit memiliki peran penting dalam menjaga minat investor di antara pihak lain yang menggunakan informasi keuangan. Dengan demikian, laporan keuangan harus disusun sesuai dengan Standar Akuntansi Internasional (IAS) dan disahkan oleh auditor eksternal yang memastikan bahwa informasi keuangan mencerminkan posisi sebenarnya perusahaan. Oleh karena itu, biaya audit mempertimbangkan faktor esensial yang mencerminkan keandalan laporan keuangan yang dipublikasikan.

Intinya, penelitian ini bertujuan untuk mengeksplorasi semua faktor yang dapat mempengaruhi biaya audit eksternal pada perusahaan manufaktur yang terdaftar di Bursa Efek Indonesia (BEI) dan menghasilkan model untuk membantu pihak terkait.

Literatur sebelumnya telah melakukan dan membahas faktor-faktor yang mempengaruhi biaya audit eksternal yang hanya mencakup negara-negara maju. Selain itu, sebagian besar penelitian sebelumnya menggunakan empat hingga lima variabel yang dapat berpengaruh pada biaya audit seperti (ukuran, profitabilitas, risiko, jenis industri dan kompleksitas) (Khan, A.; Muttakin, M. B \& Siddique, 2015). Oleh karena itu, pentingnya penelitian ini muncul dari fakta bahwa penelitian ini 
mempertimbangkan faktor-faktor yang lebih komprehensif yang dapat mempengaruhi biaya audit. Selain itu, literatur sebelumnya telah mempertimbangkan biaya audit sebagai faktor yang berpengaruh dalam audit eksternal. Namun, sebagian besar penelitian tersebut dilakukan di negara maju.

Oleh karena itu, penelitian ini menghasilkan pandangan yang lebih komprehensif atas biaya audit karena mempertimbangkan sembilan faktor yang mungkin berdampak pada biaya audit. Selain itu, penelitian ini bertujuan untuk membangun model untuk menentukan faktor-faktor utama yang berpengaruh terhadap biaya audit eksternal, serta diharapkan dapat memperkaya kemampuan auditor untuk memperkirakan biaya audit. Selain itu, penelitian ini juga memberikan beberapa rekomendasi untuk mengembangkan karir audit dan regulator di Indonesia.

Bagian selanjutnya menyajikan tinjauan pustaka yang terkait dengan penelitian saat ini untuk menentukan faktor utama yang mempengaruhi biaya audit. Selain itu, bagian selanjutnya mencakup kerangka teori untuk penelitian ini.

\section{KAJIAN LITERATUR PENGEMBANGAN HIPOTESIS}

DAN

Selama tiga dekade terakhir, banyak literatur telah membahas permasalahan terkait biaya audit (Ho, J. L., \& Kang, 2013) (M. Kamolsakulchai, 2015). Tujuan utama dari penelitian ini adalah untuk menemukan faktor-faktor yang dapat menentukan besarnya biaya audit. Sejak 1980-an, (Simunic, 1980) mengemukakan bahwa ukuran bisnis dan kompleksitas perusahaan merupakan dua faktor penting yang menentukan biaya audit. Selanjutnya, (Ho, J. L., \& Kang, 2013) mengemukakan bahwa beban kerja audit, kompleksitas, risiko, masukan audit dan ukuran KAP merupakan faktor-faktor yang mempengaruhi penentuan biaya audit. Pandangan ini terdapat dalam literatur dengan beberapa pengecualian. Sebagai contoh, (M. Kamolsakulchai, 2015) dan (Khan, A.; Muttakin, M. B \& Siddique, 2015) menemukan hasil yang membingungkan yang menunjukkan bahwa laba, kompleksitas usaha dan jumlah anak perusahaan bukan merupakan variabel yang signifikan dalam menentukan biaya audit. Dengan demikian, untuk meluruskan perdebatan ini, penelitian ini meninjau sejumlah besar penelitian sebelumnya untuk mengekstraksi faktor yang paling mungkin yang diharapkan mempengaruhi biaya audit Indonesia.

Baru-baru ini, (Naser, K., \& Hassan, 2016) mempelajari kriteria penentuan biaya audit pada perusahaan nirlaba yang aktif di Uni Emirat Arab dengan mengukur faktorfaktor berikut; ukuran bisnis, independensi komite audit, kompleksitas, profitabilitas, risiko, jenis industri dan keterlambatan laporan audit. Temuan mereka menunjukkan hubungan yang kuat antara ukuran perusahaan, independensi komite audit, dan biaya audit. Di sisi lain, mereka menemukan korelasi negatif antara kompleksitas bisnis dan biaya audit eksternal yang menunjukkan bahwa biaya audit tidak berkorelasi signifikan dengan profitabilitas perusahaan, risiko, jenis industri, keterlambatan laporan audit dan status kantor audit. Dalam penelitiannya, Alzeban \& Sawan (2016) menyimpulkan bahwa biaya audit eksternal dipengaruhi oleh kepatuhan terhadap Standar Akuntansi Internasional (IAS) dan tingkat audit internal, yang menunjukkan bahwa kepatuhan terhadap standar tersebut membutuhkan proses audit yang lebih banyak dan peningkatan biaya audit.

Di sisi lain, (Nicolaisen, M. \& Asbjornsen, 2009) menguji hubungan normal antara struktur kepemilikan perusahaan dan biaya audit yang dibayarkan kepada auditor eksternal. Hasil penelitian mereka menunjukkan hubungan positif antara biaya audit dan perusahaan kepemilikan asing. Shan \& Troshani (2016) mempelajari hubungan antara Extensible Business Reporting Language (XBRL) dan biaya audit untuk sejumlah perusahaan yang beroperasi di negara berkembang. Hasil penelitian tersebut menunjukkan bahwa (XBRL) berpengaruh negatif terhadap biaya audit. Selain itu, Lin \& Yen (2016) menemukan bahwa perusahaan 
yang menerapkan IFRS dalam laporan keuangan mereka membayar biaya audit lebih tinggi. (Musah, 2017) meramalkan bahwa ukuran bisnis perusahaan Ghana, perusahaan internasional, afiliasi perusahaan audit dan profitabilitas adalah signifikan ketika menentukan audit. Penelitian terbaru yang dilakukan oleh Tran, et al., (2019) mengemukakan sejumlah faktor yang berpengaruh positif terhadap biaya audit, yaitu; karakteristik perusahaan audit, auditor, karakteristik auditor dan hubungan antara perusahaan audit dengan klien. Penelitian tersebut juga mengungkapkan bahwa usia dan kualifikasi auditor berdampak pada biaya audit, sedangkan (Paramita, 2016) mendeteksi korelasi yang signifikan antara ukuran dan reputasi KAP dengan kualitas audit, juga mereka menemukan hubungan yang kuat antara biaya audit yang dibebankan dan kualitas audit.

Literatur lainnya menguji hubungan antara spesialisasi industri dan biaya audit. Menariknya, hasilnya inklusif mengenai pengaruhnya yang menunjukkan hubungan negatif antara industri auditor dan biaya audit (Fleming, D., Hee, K., \& N. Romanus, 2014), sedangkan (Nagy, 2014) menunjukkan hubungan positif yang signifikan untuk spesialisasi audit dan biaya audit.

Terdapat kajian literatur yang luas yang mempelajari hubungan antara biaya audit dan klasifikasi perusahaan audit. Beberapa temuan menunjukkan hubungan positif antara biaya audit dan klasifikasi perusahaan audit, serta, auditor mengambil biaya audit yang lebih tinggi untuk perusahaan berisiko tinggi (Rustam, R., Rashid, K., Zaman, 2013). Hasil serupa ditangkap saat menyelidiki hubungan antara biaya audit dan tata kelola perusahaan. (Larcker, D. F., 2004) meneliti sejauh mana variabel tata kelola perusahaan seperti (independensi audit, pengalaman komite audit, dan litigasi penipuan) dapat mempengaruhi biaya audit. Hasilnya menunjukkan korelasi positif antara penipuan dan biaya audit.

Dalam konteks Yordania, (Said Suwaidan, M., \& Qasim, 2010) menemukan bahwa manajer Yordania mengutamakan objektivitas, kompetensi dan prestasi kerja ketika memilih perusahaan audit mereka.

Secara keseluruhan, penelitian sebelumnya telah menunjukkan bahwa faktorfaktor yang mempengaruhi biaya auditor tidak selalu terdiri. Salah satu penjelasan dari perbedaan ini dapat merujuk pada pernyataan posisi keuangan perusahaan, negosiasi dengan klien mengenai anggaran komersial, tahap kerja tambahan selama proses audit (Maarse, 2018), lingkungan penelitian dan peraturan perundang-undangan yang berbeda dari satu negara ke lain. Selain itu, penelitian sebelumnya (Dou, C., Yuan, M., \& Chen, 2019) menunjukkan bahwa karakteristik pelanggan memiliki pengaruh yang kuat terhadap biaya audit, sedangkan penelitian lain menunjukkan bahwa karakteristik audit memiliki pengaruh yang paling kuat terhadap biaya audit (Tran, M., Pham, T., Phan, T., Hoang, T., Do, D., \& Dinh, 2019). Selain itu, terdapat kesepakatan umum dalam literatur tentang dampak ukuran bisnis, kompleksitas proses audit, risiko audit, ukuran kantor audit, waktu yang dibutuhkan oleh audit, dan integritas sistem pengendalian internal. .

Dalam hal ini, penelitian ini membahas tentang hasil yang tidak konsisten yang ditemukan dalam literatur sebelumnya tentang faktor-faktor yang dapat mempengaruhi biaya audit eksternal. Untuk menginformasikan perdebatan ini, penelitian ini berfokus pada bagaimana mengidentifikasi faktor-faktor yang perlu dipertimbangkan saat menentukan biaya audit, dan bagaimana membangun model baru untuk membantu perusahaan dalam menentukan biaya audit. Bagian selanjutnya melengkapi variabel independen yang diadopsi dan bagaimana membangun hipotesis penelitian.

\section{Ukuran Klien}

Literatur sebelumnya menunjukkan konsensus bahwa faktor utama yang mempengaruhi biaya audit eksternal adalah ukuran klien (Palmrose, 1986) (Simunic, 1980) (Musah, 2017). Penelitian tersebut antara lain telah menentukan tiga faktor yang mempengaruhi biaya audit, yaitu; ukuran 
perusahaan, tingkat kompleksitas bisnis dan risiko klien. Mereka juga memanfaatkan total aset perusahaan untuk mengukur ukuran klien, dan menemukan hubungan positif yang signifikan antara biaya audit dan ukuran bisnis. Dengan demikian, metode serupa akan digunakan dalam penelitian ini untuk menghasilkan hipotesis sebagai berikut:

H1: Ada hubungan yang kuat antara ukuran klien dan biaya audit dalam perusahaan manufaktur yang terdaftar di Bursa Efek Indonesia (BEI).

\section{Profitabilitas Klien}

Profitabilitas dianggap sebagai indikator penting untuk mengevaluasi kinerja manajemen dalam menggunakan asetnya secara efektif. Profitabilitas dapat didefinisikan sebagai penggunaan sumber daya perusahaan secara efektif dan pengembalian aset yang tinggi. Perusahaan yang sangat menguntungkan biasanya membayar biaya audit yang lebih tinggi karena waktu dan upaya ekstra yang diperlukan untuk mengumpulkan dan menguji bukti audit. Ini menunjukkan hubungan positif antara profitabilitas dan biaya audit (Simunic, 1980). Namun, Hossain, \& Sobhan, (2019), dalam penelitiannya tidak menemukan adanya hubungan antara profitabilitas dan biaya audit. Oleh karena itu, penelitian ini menggunakan laba bersih perusahaan dibagi dengan total aset pada akhir tahun untuk mengukur profitabilitas, seperti (Simunic, 1980).

$\mathrm{H} 2$ : Ada hubungan yang kuat antara profitabilitas klien dan biaya audit dalam perusahaan manufaktur yang terdaftar di Bursa Efek Indonesia (BEI).

\section{Risiko Klien}

Risiko audit dianggap sebagai elemen utama lain dalam menentukan biaya audit. Risiko dapat diartikan sebagai peluang kerugian. Auditor diharapkan berhati-hati saat mengungkapkan pendapatnya untuk menghindari litigasi di masa mendatang. Hal ini membutuhkan waktu dan tenaga kerja ekstra untuk menyelesaikan proses audit, sehingga meningkatkan biaya audit. Argumen ini didukung oleh (Paramita, 2016) yang berpendapat bahwa auditor mengenakan biaya audit yang lebih tinggi pada perusahaan yang memiliki risiko yang lebih tinggi. Akibatnya, biaya audit eksternal secara signifikan dikaitkan dengan risiko klien (Dou, C., Yuan, M., \& Chen, 2019). Selain itu, bukti lain menunjukkan hubungan yang kuat antara tingkat leverage perusahaan dan risiko perusahaan (Simunic, 1980). Oleh karena itu, risiko klien dapat diukur dengan rasio leverage sebagai total hutang terhadap total asset dengan hipotesis sebagai berikut.

H3: Ada hubungan yang kuat antara risiko klien dan biaya audit dalam perusahaan manufaktur yang terdaftar di Bursa Efek Indonesia (BEI).

\section{Kompleksitas Klien}

Masuk akal dalam konteks akuntansi bahwa lebih banyak anak perusahaan mengarah pada operasi dan aktivitas bisnis yang lebih besar. Hal ini mengakibatkan semakin banyaknya kegiatan audit yang akan meningkatkan biaya audit. Dengan kata lain, meningkatkan operasi klien atau jumlah produk yang terdiversifikasi atau asing memerlukan lebih banyak pekerjaan audit. Oleh karena itu, perusahaan audit membebankan biaya audit yang lebih tinggi (Naser, K., \& Hassan, 2016). Lebih lanjut Simon (1985) mengungkapkan bahwa jumlah cabang dan persentase penanaman modal asing pada suatu perusahaan merupakan aspek utama dari kompleksitas. Oleh karena itu, kompleksitas perusahaan diharapkan berhubungan positif dengan remunerasi auditor eksternal.

H4: Ada hubungan yang kuat antara kompleksitas klien dan biaya audit dalam perusahaan manufaktur yang terdaftar di Bursa Efek Indonesia (BEI).

\section{Jenis Industri Klien}

Perusahaan dalam suatu industri diharapkan melibatkan jenis keahlian tertentu oleh auditor disertai dengan jam kerja ekstra 
dibandingkan sektor lain. Fleming et al., (2014) berpendapat bahwa ada hubungan negatif antara sektor perusahaan dan biaya audit. Namun, (Nagy 2014; Tran et al., 2019) menggambarkan hubungan positif antara sektor perusahaan dan biaya audit. Oleh karena itu, penelitian ini tidak mendeteksi dasar pengukuran untuk faktor ini. Meskipun demikian, penelitian sebelumnya menyatakan bahwa perusahaan manufaktur cenderung mengungkapkan informasi yang lebih sukarela yang pada gilirannya membutuhkan lebih banyak biaya audit. Dengan demikian, penelitian saat ini menggunakan variabel dummy untuk mengukur variabel ini. Oleh karena itu hipotesisnya sebagai berikut.

H5: Ada hubungan yang kuat antara jenis industri klien dan biaya audit pada perusahaan manufaktur yang terdaftar di Bursa Efek Indonesia (BEI).

\section{Status Kantor Audit}

Klasifikasi kantor audit merupakan elemen signifikan yang mempengaruhi biaya audit. (Lennox, 1999) mencatat bahwa auditor besar dapat menawarkan kualitas audit yang lebih baik terhadap keandalan laporan keuangan klien dibandingkan dengan yang kecil. Hal ini diharapkan dapat menghasilkan biaya audit yang lebih tinggi yang dibebankan pada perusahaan-perusahaan tersebut (Paramita, 2016). Temuan penelitian tersebut menunjukkan hubungan positif antara biaya audit dan klasifikasi kantor audit. Konsisten dengan Simunic (1980), penelitian ini menggunakan variabel dummy untuk perusahaan audit yang termasuk big four dan mengajukan hipotesis sebagai berikut:

H6: Ada hubungan yang kuat antara status kantor audit dan biaya audit pada perusahaan manufaktur yang terdaftar di Bursa Efek Indonesia (BEI).

\section{Audit Report Lag}

Di Indonesia seperti di banyak negara, periode bisnis berakhir pada 31 Desember. Perusahaan Indonesia menjalani proses audit dimulai pada 31 Desember hingga 31 Maret.
Akibatnya, auditor biasanya mengenakan harga lebih tinggi pada rentang waktu ini. Hassan, (2018) mencatat bahwa penyusunan laporan audit melalui jeda periode antara akhir tahun hingga 31 April tidak menunjukkan korelasi yang signifikan dengan biaya audit. Sedangkan Dao (2014) menemukan hubungan negatif antara audit report lag dan biaya audit. Oleh karena itu, dapat disusun hipotesis sebagai berikut.

H7: Terdapat hubungan yang kuat antara audit report lag dan biaya audit pada perusahaan manufaktur yang terdaftar di Bursa Efek Indonesia (BEI).

\section{Independensi Komite Audit}

Independensi komite audit dianggap sebagai faktor berpengaruh lain yang dapat mempengaruhi biaya audit secara positif atau negatif (Klein, 2002). (Ketaren, 2016) menunjukkan korelasi positif antara independensi komite audit dan biaya audit. Artinya, jumlah anggota independen dalam komite audit (dari luar perusahaan) membutuhkan biaya audit yang lebih besar dan sebaliknya. Surat Edaran Bapepam No. SE03/PM/2000 mensyaratkan komite harus independen dari dewan direksi. Mengingat fakta ini, penelitian saat ini menguji faktor ini dengan mengukur jumlah anggota independen komite audit dari total. Oleh karena itu, dapat disusun hipotesis sebagai berikut.

H8: Terdapat hubungan yang kuat antara independensi komite audit dengan fee audit pada perusahaan manufaktur yang terdaftar di Bursa Efek Indonesia (BEI).

\section{Rotasi Auditor}

Literatur akuntansi menunjukkan bahwa perusahaan audit mengenakan biaya lebih tinggi pada awal penugasan. Biaya ini secara bertahap berkurang pada tahun-tahun mendatang karena prosedur berulang dan keakraban yang diperoleh dari pekerjaan tersebut. (Malagila, J., Bhavani, G., \& Amponsah, 2020) menemukan bahwa rotasi audit meningkatkan kepercayaan dalam proses audit dan berdampak negatif pada 
biaya audit. Penelitian saat ini menggunakan variabel dummy untuk mengukur variabel ini. Oleh karena itu, dapat disusun hipotesis sebagai berikut.

H9: Ada hubungan yang kuat antara waktu auditor dengan perusahaan yang sama dan biaya audit pada perusahaan manufaktur yang terdaftar di Bursa Efek Indonesia (BEI).

\section{Biaya Audit (Variabel Dependen)}

Biaya audit adalah jumlah uang yang dibayarkan kepada auditor untuk proses audit yang telah dilakukan. Ada beberapa faktor yang mempengaruhi biaya audit. Misalnya: waktu yang dihabiskan dalam proses audit, layanan yang dibutuhkan, dan jumlah karyawan yang terlibat dalam proses audit (Hassan, 2018). Di sisi lain, terdapat faktor non-kuantitatif penting lainnya yang mempengaruhi biaya audit seperti biaya audit internal, tingkat penggunaan standar akuntansi secara konsisten, tingkat aktivitas klien ganda dan tingkat persaingan antar auditor.

Secara keseluruhan, terdapat beberapa penelitian yang meneliti faktor-faktor yang mempengaruhi biaya audit eksternal pada perusahaan manufaktur yang terdaftar di Bursa Efek Indonesia (BEI) selama periode 5 tahun. Tak satu pun dari penelitian sebelumnya yang menguji biaya audit sebagai masalah penelitian yang utama kecuali dalam konteks topik keuangan dan akuntansi lainnya atau dengan cakupan yang kecil. Oleh karena itu, penelitian ini bermaksud untuk memberikan pandangan yang lebih komprehensif atas topik tersebut.

\section{METODE PENELITIAN}

Adapun pada tahun 2018, jumlah emiten di Bursa Efek Indonesia (BEI) adalah 619. Sesuai dengan aturan yang ditetapkan BEI bahwa perusahaan publik wajib menyusun laporan keuangan yang telah diaudit oleh auditor eksternal guna meningkatkan kepercayaan investor terhadap perusahaan. Oleh karena itu, sejumlah teknik analisis digunakan dalam penelitian ini untuk memastikan bahwa hasil yang diharapkan dapat dicapai dan untuk mengukur keefektifan model. Oleh karena itu, penelitian ini menggunakan analisis regresi dan korelasi (matriks korelasi), statistik deskriptif dan regresi linier, untuk menguji kemampuan model ini dalam menentukan biaya audit. Peneliti juga menerapkan analisis multivariat untuk setiap tahun (5 tahun) serta untuk gabungan lima tahun.

\section{Populasi dan Sampel}

Populasi penelitian terdiri dari seluruh perusahaan manufaktur yang terdaftar di Bursa Efek Indonesia (BEI) antara tahun 2014 hingga 2018. Dengan demikian, sebanyak 165 perusahaan manufaktur dilibatkan, karena sektor ini berperan penting dalam perkembangan ekonomi Indonesia.

Oleh karena itu, pembuatan model yang mampu memahami faktor-faktor yang digunakan untuk menentukan biaya audit diharapkan sangat bermanfaat. Selain itu, sejumlah perusahaan dikeluarkan dari penelitian ini karena kurangnya data yang diperlukan atau biaya audit yang tidak diumumkan. Oleh karena itu, sampel akhir adalah 76 perusahaan sehingga total pengamatan selama lima tahun sebanyak 380 perusahaan untuk menggeneralisasi hasil penelitian dan mengatasi ukuran sampel kecil dari pasar Indonesia.

\section{Variabel Dependen}

Variabel dependen dalam penelitian ini adalah biaya audit yang akan diukur dengan jumlah normal yang dibayarkan kepada auditor atas layanan audit yang diberikan.

\section{Variabel Independen dan Pengukurannya}

Variabel independen yang digunakan dalam penelitian ini disajikan pada Tabel 1 . 
Tabel 1

Operasionalisasi Variabel

\begin{tabular}{|c|c|c|c|}
\hline$\underset{1}{\text { Varíbe }}$ & Tipe & Kode & Proksi \\
\hline Biaya audit & Dependen & FEE & $\begin{array}{l}\text { Bixya andit Eunkur dengan logaritma } \\
\text { natual dari biaya andit }\end{array}$ \\
\hline Ukuran perusahsan & Independen & SIZE & Logaritma natural dari total ase. \\
\hline Profitabilitas & Independen & PROF & $\begin{array}{l}\text { Profitabilitas diukour dengan pendapatan / } \\
\text { penjualan bersih. }\end{array}$ \\
\hline Ricko Peruszhasn & Tndependen & RI5K & $\begin{array}{l}\text { Kisiko druker dengan total liabilitas / tofal } \\
\text { ase. }\end{array}$ \\
\hline $\begin{array}{l}\text { Kompleksitas } \\
\text { perusahsun }\end{array}$ & Independen & COMP & $\begin{array}{l}\text { Dinkaur berdasarkan jumlah anak } \\
\text { perwsahnan. }\end{array}$ \\
\hline Industi & Independen & IND & Perusahasn manufaktur \\
\hline Rotasi Audinor & Tndependen & RAU & $\begin{array}{l}\text { hika perusahasan mentzanti suditor } \\
\text { teilebih dahulu }\end{array}$ \\
\hline Status kantor wudit & Independen & BIO & $\begin{array}{l}1 \text { matuk empat perusabsan besar (Big 4), } 0 \\
\text { jika hinnya }\end{array}$ \\
\hline Audin repoet Lag & Independen & ARL. & 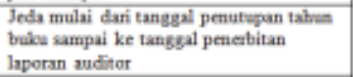 \\
\hline $\begin{array}{l}\text { Kemite andit } \\
\text { independen }\end{array}$ & Independen & ADCOM & $\begin{array}{l}\text { Proporsi anggota independen pada } \\
\text { komite audit. }\end{array}$ \\
\hline
\end{tabular}

\section{Model Regresi}

Model regresi berganda yang melibatkan variabel yang diadopsi dikembangkan untuk menjawab hipotesis penelitian ini:

FEE $=\alpha_{0}+\alpha_{1}$ SIZE $+\alpha_{2}$ PROF $+\alpha_{3}$ RISK + $\alpha_{4} \mathrm{COMP}+\alpha_{5} \mathrm{IND}+\alpha_{6} \mathrm{RAU}+\alpha_{7} \mathrm{BIG}+\alpha_{8}$ $\mathrm{ARL}+\alpha_{9} \mathrm{ADCOM}+e$.

Tabel 2

Statistik Deskriptif

\begin{tabular}{|c|c|c|c|c|c|}
\hline & $\mathbf{N}$ & Minimum & Maximum & Mean & Std. Deviation \\
\hline Biaya Audit (FEE) & 380 & 0.00000 & 212930.00000 & 32127.0131250 & 34378.22426022 \\
\hline Risiko klien (RISK) & 380 & 0.08 & 227.53 & 36.6224 & 29.42676 \\
\hline Profitabilitas Klien (PROF) & 380 & $-937.70-$ & 362.16 & $-5.2358-$ & 93.37671 \\
\hline Ukuran Klien (SIZE) & 380 & 3.83 & 9.25 & 7.2353 & 0.91567 \\
\hline $\begin{array}{c}\text { Kompleksitas Klien } \\
\text { (COMP) }\end{array}$ & 380 & 0.00 & 16.00 & 1.4236 & 1.94911 \\
\hline Audit Report Lag (ARL) & 380 & 0.00 & 253.00 & 61.5269 & 30.49894 \\
\hline Status Kantor Audit (BIG) & 380 & 0.00 & 1.00 & 0.3611 & 0.48116 \\
\hline Industri (IND) & 380 & 0.00 & 1.00 & 0.7222222 & 0.289387 \\
\hline $\begin{array}{c}\text { Komite audit independen } \\
\text { (ADCOM) }\end{array}$ & 380 & 0.01 & 4.00 & 0.02172 & 0.4950738 \\
\hline Rotasi Auditor (RAU) & 380 & 0.00 & 1.00 & 0.1918487 & 0.2475685 \\
\hline Valid N (list wise) & 380 & & & & \\
\hline
\end{tabular}

Sumber: Data penelitian diolah (2020)

Tabel 3

Matriks Korelasi

\begin{tabular}{|c|c|c|c|c|c|c|c|c|c|}
\hline $\begin{array}{l}\text { Pearson } \\
\text { Correlation }\end{array}$ & FEE & RISK & PROF & SIZE & COMP & ARL & BIG & RAU & ADCOM \\
\hline FEE & 1 & 0.112 & 0.016 & $0.125^{\cdots \cdots}$ & $0.161^{\cdots+\cdots}$ & 0.013 & $0.220^{\cdots \cdots}$ & $0.178 * *$ & 0.084 \\
\hline RISK & 0.112 & 1 & $-0.097-$ & -0.064- & 0.081 & $0.245^{*-\pi}$ & $\begin{array}{l}-0.017- \\
\end{array}$ & -0.070 & 0.064 \\
\hline PROF & 0.016 & 0.097 & 1 & 0.061 & $-0.077-$ & $-0.074-$ & 0.013 & 0.314 & 0.401 \\
\hline SIZE & $0.125^{\pi-1}$ & 0.064 & 0.061 & 1 & $0.257^{* \pi}$ & 0.047 & $0.133^{*}$ & $0.381 * *$ & 0.378 \\
\hline COMP & $0.161^{\text {**F }}$ & 0.081 & $-0.077-$ & $0.257^{\text {** }}$ & 1 & $0.189^{\text {** }}$ & $0.208^{\text {** }}$ & 0.023 & 0.0312 \\
\hline ARL & 0.013 & $0.245^{\cdots-1}$ & $-0.074-$ & 0.047 & $0.189^{*}$ & 1 & $0.260^{\cdots \cdots}$ & 0.165 & 0.452 \\
\hline $\mathrm{BIG}$ & $0.220^{\cdots-n}$ & 0.017 & 0.013 & $0.133^{*}$ & $0.208^{m}$ & 0.260 & 1 & 00.051 & 0.0189 \\
\hline RAU & $0.178^{* *}$ & -0.070 & 0.314 & $0.381 * *$ & 0.023 & 0.165 & 00.051 & 1 & 0.213 \\
\hline ADCOM & 0.084 & 0.064 & 0.401 & 0.378 & 0.0312 & 0.452 & 0.0189 & 0.213 & 1 \\
\hline
\end{tabular}

Di mana:

$\begin{array}{ll}\text { FEE } & \text { : Biaya audit } \\ \text { SIZE } & \text { : Ukuran perusahaan } \\ \text { PROF } & \text { : Profitabilitas } \\ \text { RISK } & \text { : Risiko Perusahaan } \\ \text { COMP } & : \text { Kompleksitas perusahaan } \\ \text { IND } & : \text { Industri } \\ \text { RAU } & \text { : Rotasi auditor } \\ \text { BIG } & \text { : Status kantor audit } \\ \text { ARL } & : \text { Audit report lag } \\ \text { ADCOM } & \text { : Independensi komite audit } \\ \alpha_{0} & : \text { Intercept } \\ \alpha_{1-9} & : \text { Coefficients } \\ e & : \text { Error term }\end{array}$

\section{HASIL PENELITIAN}

\section{Statistik Deskriptif Variabel Penelitian}

Tabel 2 menyajikan temuan statistik deskriptif yang dilakukan pada variabel penelitian untuk mengidentifikasi indikator umum variabel independen dan dependen. 
**. Correlation is significant at the 0.01 level (2-tailed).

*. Correlation is significant at the 0.05 level (2-tailed).

Sumber: Data penelitian diolah (2020)

Tabel 4

Ilutrasi Temuan Regresi Berganda untuk Tahun 2014, 2015, 2016, 2017, 2018

\begin{tabular}{|c|c|c|c|c|c|c|c|c|c|c|c|c|c|}
\hline \multirow[t]{2}{*}{ Variable } & \multicolumn{2}{|c|}{2014} & \multicolumn{2}{|c|}{2015} & \multicolumn{2}{|c|}{2016} & \multicolumn{2}{|c|}{2017} & \multicolumn{2}{|c|}{2018} & \multicolumn{2}{|c|}{ For all years } & \multirow[b]{2}{*}{ VIF } \\
\hline & coff & p-value & coff & $\mathrm{p}$-value & coff & p-value & coff & p-value & coff & p-value & coff & p-value & \\
\hline FEE & 5.37 & 0.00 & 4.84 & 0.000 & 5.61 & 0.00 & 6.17 & 0.000 & 7.61 & 0.000 & 5.99 & 0.000 & 1.15 \\
\hline SIZE & 0.642 & 0.00 & 0.516 & 0.000 & 0.489 & 0.00 & 0.551 & 0.000 & 0.494 & 0.006 & 0.538 & 0.000 & 1.25 \\
\hline PROF & 0.016 & 0.03 & 0.171 & 0.401 & 0.031 & 0.20 & 0.025 & 0.047 & 0.041 & 0.042 & 0.081 & 0.031 & 1.05 \\
\hline RISK & -0.088 & 0.01 & -0.079 & 0.593 & -0.085 & 0.03 & -0.082 & 0.031 & -0.020 & 0.011 & -0.641 & -0.034 & 1.28 \\
\hline COMPL & 0.089 & 0.02 & 0.122 & 0.388 & 0.109 & 0.02 & 0.198 & 0.011 & 0.113 & 0.061 & 0.027 & 0.015 & 1.56 \\
\hline IND & 0.109 & 0.00 & 0.109 & 0.189 & 0.275 & 0.05 & 0.012 & 0.276 & 0.218 & 0.003 & 0.148 & 0.041 & 1.44 \\
\hline BIG & 0.048 & 0.04 & 0.122 & 0.223 & 0.141 & 0.08 & 0.009 & 0.118 & 0.320 & 0.091 & 0.019 & 0.065 & 1.31 \\
\hline ARL & 0.248 & 0.12 & 0.109 & 0.182 & 0.281 & 0.31 & 0.014 & 0.267 & 0.198 & 0.011 & 0.171 & 0.041 & 1.29 \\
\hline ADCOM & 0.201 & 0.23 & 0.087 & 0.005 & 0.265 & 0.00 & 0.176 & 0.116 & 0.026 & 0.021 & 0.014 & 0.028 & 1.81 \\
\hline RAU & 0.198 & 0.16 & 0.245 & 0.221 & 0.036 & 0.14 & 0.043 & 0.137 & 0.243 & 0.172 & 0.124 & 0.052 & 1.27 \\
\hline $\mathrm{R}$ & \multicolumn{2}{|c|}{0.765} & \multicolumn{2}{|c|}{0.773} & \multicolumn{2}{|c|}{0.793} & \multicolumn{2}{|c|}{0.778} & \multicolumn{2}{|c|}{0.781} & \multicolumn{2}{|c|}{77,9} & \\
\hline $\mathrm{R} 2$ & \multicolumn{2}{|c|}{0.749} & \multicolumn{2}{|c|}{0.753} & \multicolumn{2}{|c|}{0.771} & \multicolumn{2}{|c|}{0.75 .9} & \multicolumn{2}{|c|}{0.76} & \multicolumn{2}{|c|}{75.8} & \\
\hline $\begin{array}{c}\text { modelF } \\
\text { test }\end{array}$ & \multicolumn{2}{|c|}{14.556} & \multicolumn{2}{|c|}{16.984} & \multicolumn{2}{|c|}{17.421} & \multicolumn{2}{|c|}{16.449} & \multicolumn{2}{|c|}{15.769} & \multicolumn{2}{|c|}{$\begin{array}{c}40.824 \\
\mathrm{P}=0.000\end{array}$} & \\
\hline
\end{tabular}

Sumber: Data penelitian diolah (2020)

Hasil analisis deskriptif menunjukkan bahwa biaya audit yang dibayarkan oleh perusahaan bervariasi dari nol hingga 212930. Ukuran perusahaan diukur dengan logaritma natural dari total aset perusahaan dengan mean sebesar 7.2353. Nilai profitabilitas berkisar antara -937 hingga 352,16, dengan rata-rata $-5,235$ mengindikasikan adanya kerugian di beberapa perusahaan. Selain itu, variabel risiko menunjukkan penyebaran nilai dari 0,08 hingga 227,53, dengan rata-rata 0,36 yang menunjukkan bahwa sebagian besar perusahaan bergantung pada utang untuk membiayai aktivitasnya. Faktanya, 36\% aset perusahaan dibiayai oleh hutang.

Kompleksitas perusahaan dimulai dari 0 hingga 16, yang menunjukkan bahwa beberapa perusahaan tidak memiliki anak perusahaan, sementara yang lain memiliki 16 anak perusahaan. Selanjutnya, keterlambatan laporan audit menunjukkan rata-rata yang diharapkan 61 hari untuk menyelesaikan laporan. Selain itu, 31\% sampel diaudit oleh salah satu kantor audit big four, dan 19\% mengganti auditor mereka selama tiga tahun pertama kesepakatan audit. Terakhir, jumlah anggota komite audit independen berkisar antara 1-4 dengan rata-rata 2,17 anggota.

\section{Hasil Pengujian dan Analisis Empiris}

Bagian ini membahas tentang uji analisis dan temuan utama. Matriks korelasi untuk variabel utama diilustrasikan pada Tabel 3. Selanjutnya, Tabel 4 menggambarkan analisis regresi berganda untuk variabel penelitian yang bertujuan untuk memprediksi biaya audit.

Tabel 4 menyajikan beberapa regresi untuk model estimasi. Pengujian tersebut akan memastikan kesesuaian data (uji Robustness), serta penelitian ini mengadopsi uji regresi berganda untuk semua variabel untuk mendeteksi pengaruhnya terhadap biaya audit. Nilai dari semua variabel VIF kurang dari 10 menunjukkan tidak adanya masalah multikolinearitas. Adjusted R2 sebesar 75\% yang menunjukkan kesesuaian model untuk menginterpretasikan deviasi dengan biaya audit. Hasil ini juga didukung oleh uji $F$ untuk model estimasi $(\beta=40.84$; $p$-value $=0.000)$. Oleh karena itu, hasil penelitian menunjukkan bahwa data memiliki kemampuan 
menjelaskan $75 \%$ penyimpangannya. Di sisi lain, variabel independen menunjukkan halhal berikut: ukuran klien berpengaruh positif terhadap biaya audit, seperti yang dijelaskan melalui ( $\mathrm{p}$-value $<0,05$ ). Oleh karena itu, hasil penelitian ini konsisten dengan penelitian sebelumnya seperti (Khikia, 2015) (Musah, 2017). Selain itu, hasil menunjukkan bahwa ukuran klien dikaitkan dengan aset perusahaan, aset berwujud dan tidak berwujud, besaran operasi, lini produksi, aktivitas, peristiwa dan transaksi peristiwa keuangan, membutuhkan lebih banyak waktu dan tenaga dalam pencatatan dan penyusunan laporan keuangan, yang diharapkan dapat tercermin dalam biaya audit.

Tabel 4 juga menunjukkan bahwa profitabilitas perusahaan berpengaruh terhadap biaya audit. Uji $F$ untuk model estimasi adalah $(\beta=0.03$; p-value $<0.05)$. Perusahaan berusaha untuk mencapai akurasi, kelengkapan, pengurangan biaya, dan operasi yang cepat untuk mencapai tujuannya, dan tujuan pentingnya adalah profitabilitas. Profitabilitas diartikan sebagai efisiensi manajemen perusahaan dalam menggunakan sumber dayanya. Dengan demikian, perusahaan dengan profitabilitas tinggi secara permanen mengungkapkan lebih banyak informasi untuk memotivasi calon investor berinvestasi di perusahaannya. Hasil penelitian ini menunjukkan hubungan yang lemah antara profitabilitas dan biaya audit. Hal ini menunjukkan bahwa biaya audit tidak dipengaruhi oleh profitabilitas perusahaan sehingga hipotesis kedua ditolak.

Hipotesis ketiga memprediksi tentang hubungan antara risiko klien dan biaya audit. Hasil pengujian menunjukkan adanya pengaruh negatif dan signifikan $(\beta=-0.03$; $p$ value $<0.05)$ yang konsisten dengan hasil sebelumnya (Suryani, D., \& Sitorus, 2018). Hal ini menunjukkan bahwa perusahaan bergantung pada hutang untuk membiayai operasinya yang dapat menyebabkan krisis keuangan (penyelesaian hutang). Oleh karena itu, hutang perusahaan rentan terhadap masalah keuangan (kemungkinan litigasi di masa depan) dan perusahaan audit membutuhkan lebih banyak waktu untuk memenuhi proses audit yang menyebabkan biaya audit lebih tinggi.

Hipotesis keempat memprediksi hubungan antara kompleksitas perusahaan dan biaya audit. Hasilnya mendeteksi pengaruh positif kompleksitas terhadap biaya audit, $(\beta=0,027$; $p$-value $<0,05)$. Dengan kata lain, perusahaan yang memiliki anak perusahaan lebih banyak membutuhkan usaha ekstra yang mengakibatkan biaya audit lebih tinggi.

Hipotesis kelima mengharapkan hubungan positif antara jenis industri klien dan biaya audit. Temuan penelitian ini menegaskan hubungan tersebut $(\beta=0,148$; $p$ value $=0,041<0,05)$ karena perusahaan yang memiliki teknologi tinggi membutuhkan upaya ekstra untuk menyelesaikan proses audit yang mengarah pada biaya audit yang lebih tinggi daripada sektor lainnya. Literatur sebelumnya secara konsisten menyetujui bahwa perusahaan sektor manufaktur perlu mengungkapkan informasi yang lebih wajib atau sukarela daripada di sektor lain (Khikia, 2015). Oleh karena itu, kompleksitas yang terlibat dalam penyusunan laporan keuangan bagi perusahaan manufaktur membutuhkan biaya audit yang lebih tinggi. Apalagi, perusahaan manufaktur memiliki beban ekstra terkait tanggung jawab sosialnya terhadap lingkungan. Oleh karena itu, perusahaan manufaktur berupaya menarik lebih banyak pemangku kepentingan dengan menerbitkan lebih banyak informasi untuk memenuhi kebutuhan sosial dan publik.

Hipotesis keenam memprediksi adanya hubungan yang kuat antara status kantor audit dan biaya audit. Banyak literatur mengadopsi status KAP sebagai faktor signifikan yang mempengaruhi jumlah biaya audit (Lennox, 1999). Perusahaan audit besar seperti big four memberikan laporan berkualitas lebih tinggi dan dapat diandalkan kepada pelanggan mereka dibandingkan dengan kantor audit kecil. Selain itu, kantor audit besar memiliki biaya yang lebih tinggi daripada perusahaan audit kecil (Simunic, D.A., \& Stein, 1987).

Hipotesis ketujuh berspekulasi adanya hubungan yang kuat antara audit report lag 
dan biaya audit, analisis regresi mengkonfirmasi hipotesis ini ( $\mathrm{p}$-value $=$ 0,041>0,05). Ini bertentangan dengan hipotesis penelitian ini, karena pengaruh yang kuat dengan biaya audit terdeteksi. Hal ini dapat dijelaskan dengan fakta bahwa perusahaan audit cenderung sangat sibuk selama periode ini sehingga biaya audit lebih tinggi.

Hipotesis kedelapan memprediksi hubungan yang kuat antara independensi komite audit dan biaya audit. Komite audit dianggap sebagai elemen kunci dalam perbaikan, program pengembangan, pengurangan risiko proses, peningkatan transparansi, tata kelola dan perbaikan praktik pengendalian internal. Analisis regresi mendeteksi adanya hubungan yang lemah antara independensi komite audit dan biaya audit seperti yang dijelaskan oleh beberapa literatur sebelumnya $(\beta=0.014 ; \mathrm{p}$-value $<0.05$ ), (Kikhia, 2015; Musah, 2017).

Hipotesis terakhir mengharapkan hubungan yang kuat antara rotasi audit dan biaya audit. Literatur sebelumnya mendeteksi bahwa biaya audit akan lebih tinggi pada tahun pertama dan cenderung menurun pada tahun-tahun berikutnya. Namun, hasil penelitian ini bertentangan dengan hipotesis tersebut karena analisis regresi menunjukkan tidak ada hubungan yang signifikan secara statistik antara biaya audit dan rotasi auditor. Hal ini dapat dijelaskan dengan perpanjangan kontrak yang ditandatangani antara auditor dan klien (Khikia, 2015).

\section{KESIMPULAN}

Berbagai penelitian telah menunjukkan bahwa biaya audit dapat ditentukan oleh banyak faktor. Oleh karena itu, penelitian ini menguji dampak dari beberapa faktor pada biaya audit dengan menggunakan literatur yang mencakup topik ini. Lebih penting lagi, penelitian ini mendeteksi beberapa kesenjangan dan ketidakkonsistenan dalam temuan sebelumnya dan membangun model dengan tujuan untuk mengurangi kesenjangan tersebut. Hasilnya, penelitian ini menemukan bahwa faktor terpenting yang berpengaruh signifikan terhadap biaya audit adalah: audit report lag, risiko, ukuran klien, status kantor audit, dan kompleksitas perusahaan. Selain itu, penelitian ini menemukan bahwa biaya audit berhubungan negatif dan signifikan dengan jenis industri dan profitabilitas. Di sisi lain, tidak ada hubungan yang terdeteksi antara independensi komite audit dan rotasi audit dengan biaya audit. Oleh karena itu, hasil penelitian ini sejalan dengan penelitian sebelumnya (Kikhia, 2015; Musah, 2017; Hossain, \& Sobhan, 2019; Malagila et al., 2020). Hal ini menunjukkan bahwa perusahaan manufaktur dikenakan biaya audit yang lebih rendah dibandingkan dengan sektor jasa dan keuangan. Hasil ini dapat dikaitkan dengan fakta bahwa perusahaan manufaktur Indonesia tergolong perusahaan kecil atau menengah dibandingkan dengan perusahaan manufaktur lain di negara maju. Oleh karena itu, perusahaan-perusahaan tersebut tidak memerlukan kualitas audit yang tinggi.

Selain itu, hasil penelitian ini menunjukkan hubungan yang kuat antara semua variabel yang diuji dalam menjelaskan biaya audit. $\mathrm{R}$ untuk keseluruhan model sebesar $77,9 \%$ yang berarti variabel independen yang digunakan dalam model ini memiliki kemampuan untuk menginterpretasikan lebih dari $75,8 \%$ variasi biaya audit. Salah satu konsekuensi penting mengacu pada hubungan yang kuat antara biaya audit dan ukuran perusahaan, ukuran klien, status perusahaan audit, dan kompleksitas perusahaan yang memainkan peran penting dalam model ini.

Salah satu implikasi penting dari temuan penelitian ini adalah kegunaan model yang dikembangkan dalam penelitian ini bagi perusahaan dan kantor audit untuk menentukan jumlah biaya audit yang sesuai secara akurat. Meskipun model ini lebih cocok untuk negara berkembang, namun beberapa faktor yang diteliti juga harus bermanfaat bagi beberapa negara maju. Selain itu, penelitian ini dianggap sebagai sumber dan referensi penting bagi para peneliti yang tertarik dengan profesi auditing dan perkembangannya, khususnya asosiasi profesi 
yang mengatur profesi tersebut dan berusaha untuk meningkatkannya, serta bagi kantor audit dan perusahaan dapat membantu mereka dalam memilih model yang akan digunakan dalam menentukan biaya audit.

Akhirnya, penelitian masa depan harus fokus pada faktor lain yang mempengaruhi biaya audit. Sebagai contoh, faktor nonkuantitatif yang mempengaruhi biaya audit seperti biaya audit internal, tingkat penggunaan standar akuntansi secara konsisten, tingkat aktivitas klien dan tingkat persaingan antara perusahaan audit.

\section{REFERENSI}

Dou, C., Yuan, M., \& Chen, X. (2019). Government-background customers, audit risk and audit fee. China Journal of Accounting Penelitianes, 1-22.

Fleming, D., Hee, K., \& N. Romanus, R. (2014). Auditor industry specialization and audit fees surrounding Section 404 implementation. Review of Accounting and Finance, 13(4), 353-370.

Hassan, Y. (2018). Factors influencing external audit fees of companies listed on Dubai financial market. Available at SSRN 3144631.

Ho, J. L., \& Kang, F. (2013). Auditor choice and audit fees in family firms: evidence from the S\&P 1500. Auditing: A Journal of Practice \& Theory, 32(4).

Kamolsakulchai, M. (2015). The Impact of the Audit Committee Effectiveness and Audit Quality on Financial Reporting Quality of listed company in Stocks Exchange of Thailand. Review of Integrative, Business, \& Economics Research, 4(2), 1-14.

Ketaren, L. T. C. (2016). Pengaruh Kualitas Audit Dan Karakteristik Komite Audit Terhadap Kepatuhan Pengungkapan Pengujian Penurunan Nilai Goodwill.

Khan, A.; Muttakin, M. B \& Siddique, J. (2015). Audit Fees, Auditor Choice and Stakeholder Influence: Evidence From A Family-Firm Dominated Economy. The British Accounting Review, 47.

Khikia, H. Y. (2015). Determinants of Audit Fees: Evidence from JordanNo Title.
Accounting and Finance Research, 4(1). Klein, A. (2002). Audit Committee, Board of Director Characteristics and Earnings Management. Journal of Accounting and Economics, 33(3), 375-400.

Larcker, D. F., \& R. (2004). Fees Paid to Audit Firms, Accrual Choices, and Corporate Governance. Journal of Accounting Research, 42(3), 625-628.

Lennox, C. S. (1999). Audit quality and auditor size: An evaluation of reputation and deep pockets hypotheses. Journal of Business Finance \& Accounting, 26(67), 779-805.

Malagila, J., Bhavani, G., \& Amponsah, C. (2020). The perceived association between audit rotation and audit quality: Evidence from the UAE. Journal of Accounting in Emerging Economies, 140.

Musah, A. (2017). Determinants of audit fees in a developing economy: Evidence from Ghana. International Journal of Academic Research in Business and Social Sciences, 7(11), 716-730.

Nagy, A. L. (2014). Audit partner specialization and audit fees. Managerial Auditing Journal, 29(6), 513-526.

Naser, K., \& Hassan, Y. . (2016). Factors influencing external audit fees of companies listed on Dubai Financial Market. International Journal of Islamic and Middle Eastern Finance and Management, 9(3), 346-363.

Nicolaisen, M. \& Asbjornsen, T. A. (2009). Downsizing: Family Ownership, Family Management and Listing Status: Evidence From Norwegian Firms. Thesis. Master of Science in Business and Economics.

Palmrose, Z. V. (1986). Audit Fees and Auditor Size: Further Evidence. Journal of Accounting Research, 24(1), 97-110.

Paramita, M. (2016). Pengaruh Konvergensi Ifrs, Ukuran Perusahaan, Kompleksitas Perusahaan Dan Spesialisasi Industri Auditor Terhadap Fee Audit.

Rustam, R., Rashid, K., Zaman, K. (2013). The Relationship Between Audit Committees, Compensation Incentives 
and Corporate Audit Fees In Pakistan. Economic Modelling, 31, 697-716.

Said Suwaidan, M., \& Qasim, A. (2010). External auditors' reliance on internal auditors and its impact on audit fees: An empirical investigation. 25(6), 509-525.

Simunic, D.A., \& Stein, M. T. (1987). Product differentiation in auditing: Auditor choice in the market for unseasoned new issues (No. 13).

Simunic, D. A. N. A. (1980). The Pricing of Audit Services: Theory and Evidence. 18(1).

Suryani, D., \& Sitorus, T. (2018). The client risk and the audit planning: Influence of acceptance of audit engagement. International Research Journal of Business Penelitianes, 10(3), 183-198.

Tran, M., Pham, T., Phan, T., Hoang, T., Do, D., \& Dinh, T. (2019). Factors influencing independent audit fees: Multi-group analysis PLS-SEM and moderate model. Management Science Letters, 9(10), 1599-1608. 